\title{
The Synthesis, Characterization and Structural Analysis of a Co(III) Complex of 1,10-Phenanthroline and Perfluorosebacic Acid, $\left[\mathrm{Co}(\mathrm{HL})(\text { phen })_{2}\left(\mathrm{H}_{2} \mathrm{O}\right)\right] \mathrm{L} \cdot \mathrm{H}_{2} \mathrm{O}$
}

\author{
Ibrahim Kani $^{\mathrm{a}}$, Orhan Büyükgüngör ${ }^{\mathrm{b}}$, and Filiz Şişman ${ }^{\mathrm{a}}$ \\ ${ }^{\text {a }}$ Department of Chemistry, Anadolu University 26470, Eskisehir, Turkey \\ b Department of Physics, Ondokuz Mayis University, TR-55139, Samsun, Turkey \\ Reprint requests to I. Kani. E-mail: ibrahimkani@anadolu.edu.tr
}

Z. Naturforsch. 61b, 1198 - 1204 (2006); received April 11, 2006

The hexacoordinated mononuclear $\mathrm{Co}(\mathrm{III})$ complex 1, $\left[\mathrm{Co}(\mathrm{HL})(\text { phen })_{2}\left(\mathrm{H}_{2} \mathrm{O}\right)\right] \mathrm{L} \cdot \mathrm{H}_{2} \mathrm{O}$, with the mixed ligands $\left(\mathrm{H}_{2} \mathrm{~L}=\mathrm{HO}_{2} \mathrm{C}\left(\mathrm{CF}_{2}\right)_{8} \mathrm{CO}_{2} \mathrm{H}\right.$ and 1,10-phenantroline) has been synthesized and characterized by elemental analysis, IR and UV/vis spectroscopy, magnetic susceptibility, TG analysis and $\mathrm{X}$-ray diffraction techniques. The $\mathrm{Co}(\mathrm{III})$ atom is coordinated asymmetrically by two bidentate 1,10 phenanthroline ligands, one hydrogencarboxylate ligand, $\left(\mathrm{O}_{2} \mathrm{C}\left(\mathrm{CF}_{2}\right)_{8} \mathrm{CO}_{2} \mathrm{H}\right)^{-}$, and one water molecule. In the crystal structure, there are also dicarboxylate anions and one water molecule attached through hydrogen bonds. Intermolecular $\pi-\pi$ interactions between the adjacent phenanthroline ligands also support the packing of the components.

Key words: Cobalt(III) Complex, Hydrogen Bonding, $\pi-\pi$ Interactions, Perfluorosebacic Acid,

1,10-Phenanthroline

\section{Introduction}

Research on transition metal dicarboxylate complexes with hetero aromatic $\mathrm{N}$-donor chelating ligands has been of great interest for the synthesis of coordination polymers in the past decade. A large number of publications have appeared in the literature highlighting antifungal activity of novel transition metalbased drug agents with potential applications for the control of fungal infections $[1,2]$ and interest has also occured to explore the potential applications of metal complexes containing symmetric aromatic ligands as non-radioactive probes of nucleic acid structures and as possible DNA cleaving agents [3].

The self assembly of the supramolecular coordination network is the result of coordination via several types of forces including not only coordinative bonding but also weak interactions such as hydrogen bonding [4,5], $\pi-\pi$ stacking $[6,7]$ and electrostatic interactions $[8,9]$. One of the efficient routes to form coordination polymers is to employ multifunctional ligands. For example, mono- or dicarboxylate anions are found at metal atoms in both low and high oxidation states and are bound in different modes such as monodentate and bidentate, or act as bridging ligands to two metal ions. In contrast to monocarboxylic acids, the coordination chemistry of dicarboxylic acids $\left(\left[\mathrm{O}_{2} \mathrm{C}\left(\mathrm{CH}_{2}\right)_{n} \mathrm{CO}_{2}\right]^{2-}, n=1-8\right)$ is far less developed and indeed structural information for this class of complexes is relatively scarce. In most cases, metal salts react with dicarboxylic acids to yield insoluble polymeric materials which are difficult to characterize and almost impossible to crystallize. To overcome this problem, Devereux and co-workers [10,11] showed that introduction of a second competing ligand (such as 1,10-phenanthroline, 2,2-bipyridine) lowers the dimensionality of the structures since their chelation to the metal ion leaves fewer sites for dicarboxylic acid coordination. Synergetic coordination of dicarboxylates and heteroaromatic $\mathrm{N}$-donor ligands as a source of hydrogen bonding and $\pi-\pi$ stacking interactions, respectively, has been shown to generate a variety of supramolecular motifs $[12,13]$. Most work has been restricted to the lower members of the series of saturated $\alpha, \omega$-dicarboxylate anions, and only few studies have been carried out with long chain dicarboxylates as ligands [14].

Hitherto, reports about usage of phen and long chain $\alpha, \omega$-dicarboxylate ligands to construct coordination supramolecular complexes are very scarce, and no report has been found on X-ray analyses of Co(III) complexes with phen and perfluorosebacate ligands in the 
Table 1. Crystallographic data for the title complex 1.

\begin{tabular}{|c|c|}
\hline Formula & $\mathrm{C}_{39} \mathrm{H}_{22} \mathrm{Co} \mathrm{F}_{24} \mathrm{~N}_{4} \mathrm{O}_{8}$ \\
\hline Molecular weight & 1189.54 \\
\hline Temperature [K] & $100(2)$ \\
\hline Wavelength & $0.71073 \AA$ \\
\hline Crystal system & triclinic \\
\hline Space group & $P \overline{1}$ \\
\hline$a[\AA]$ & $10.0659(5)$ \\
\hline$b[\AA]$ & $12.6196(6)$ \\
\hline$b[\AA]$ & $18.0948(8)$ \\
\hline$\alpha\left[{ }^{\circ}\right]$ & $76.454(4)$ \\
\hline$\beta\left[{ }^{\circ}\right]$ & $81.039(4)$ \\
\hline$\gamma\left[{ }^{\circ}\right]$ & $72.644(4)$ \\
\hline Volume $\left[\AA^{3}\right]$ & $2123.70(17)$ \\
\hline$Z$ & 2 \\
\hline Calculated density $\left[\mathrm{g} / \mathrm{cm}^{3}\right]$ & 1.859 \\
\hline$\mu\left[\mathrm{mm}^{-1}\right]$ & 0.569 \\
\hline$F(000)$ & 1182 \\
\hline Crystal size $[\mathrm{mm}]$ & $0.18 \times 0.34 \times 0.53$ \\
\hline$\theta$ Range $\left[{ }^{\circ}\right]$ & $1.88-26.00$ \\
\hline$h, k, l$ index ranges & $-12 \rightarrow 12,-15 \rightarrow 15,-22 \rightarrow 22$ \\
\hline Reflections collected & 30912 \\
\hline Independent reflections $\left[R_{\text {int }}\right]$ & $8356(0.0571)$ \\
\hline Reflections observed $[I \geq 2 \sigma(I)]$ & 6848 \\
\hline Absorption correction & $\begin{array}{l}\text { Integration } \\
\text { (X-RED32; Stoe \& Cie, 2002) }\end{array}$ \\
\hline Max. and min. transmission & $0.7964,0.9363$ \\
\hline Data/restrains/parameters & $8356 / 6 / 701$ \\
\hline Goodness-of-fit on $F^{2}$ & 1.018 \\
\hline$R, w R[I \geq 2 \sigma(I)]$ & $0.0320,0.0757$ \\
\hline$R, w R$ (all data) & $0.0433,0.0794$ \\
\hline \multicolumn{2}{|c|}{ Largest diff. peak and hole $\left[\mathrm{e} \AA^{-3}\right] 0.387$ and -0.487} \\
\hline
\end{tabular}

Cambridge Structural Data Base. Herein, we report first the synthesis and the crystal structure of the title compound along with its thermal and spectroscopic characterization.

\section{Results and Discussion}

Synthesis and characterization

The Co(III) complex, $\mathbf{1}$, has been synthesized from $\mathrm{Co}\left(\mathrm{CO}_{3}\right)_{y} \cdot x \mathrm{H}_{2} \mathrm{O}, 1,10$-phenanthroline and $\left[\mathrm{HO}_{2-}\right.$ $\left.\mathrm{C}\left(\mathrm{CF}_{2}\right)_{8} \mathrm{CO}_{2} \mathrm{H}\right]$, respectively, in a methanol-water mixture under aerobic conditions. Similar aerial metal oxidation of $\mathrm{Co}$ (II) has been reported by Maiti et al. [15] and John et al. [16] in methanol solution. The experimental magnetic moment value of $0.78 \mathrm{BM}$ suggests that the complex has no unpaired electron as a diamagnetic low-spin system.

The ORTEP view of the complex with the formula $\left[\mathrm{Co}(\mathrm{HL})(\text { phen })_{2}\left(\mathrm{H}_{2} \mathrm{O}\right)\right](\mathrm{L}) \mathrm{H}_{2} \mathrm{O}$ and its atom labeling are shown in Fig. 1. In Fig. 2 the unit cell is presented. The crystallographic data are summarized in Table 1. Selected bond lengths and an-
Table 2. Selected bond lengths $[\AA]$ and angles $\left[{ }^{\circ}\right]$ for complex 1.

\begin{tabular}{llll}
\hline Co1-O1 & $2.0649(15)$ & N1-Co1-N2 & $78.65(6)$ \\
Co1-O2 & $2.1393(13)$ & N1-Co1-N3 & $98.80(6)$ \\
Co1-N1 & $2.1125(16)$ & N1-Co1-N4 & $174.55(6)$ \\
Co1-N2 & $2.1354(15)$ & N2-Co1-N3 & $87.38(6)$ \\
Co1-N3 & $2.1243(16)$ & N2-Co1-N4 & $96.50(6)$ \\
Co1-N4 & $2.1257(16)$ & N3-Co1-N4 & $78.36(6)$ \\
F18-C36 & $1.350(3)$ & Co1-O2-C25 & $127.33(11)$ \\
O1-Co1-O2 & $91.93(5)$ & H1A-O1-H1B & $103(3)$ \\
O1-Co1-N1 & $90.53(6)$ & Co1-O1-H1A & $114(2)$ \\
Co1-N3-C24 & $113.33(12)$ & Co1-O1-H1B & $102.5(19)$ \\
O1-Co1-N2 & $91.65(6)$ & Co1-N1-C12 & $113.23(12)$ \\
Co1-N4-C23 & $113.57(12)$ & Co1-N1-C1 & $128.30(13)$ \\
O1-Co1-N3 & $170.22(6)$ & Co1-N2-C10 & $128.40(13)$ \\
Co1-N4-C22 & $128.60(13)$ & Co1-N2-C11 & $112.90(12)$ \\
O1-Co1-N4 & $92.10(6)$ & O2-Co1-N4 & $91.70(5)$ \\
O2-Co1-N1 & $92.98(5)$ & O2-Co1-N3 & $90.49(6)$ \\
O2-Co1-N2 & $170.92(6)$ & & \\
\hline
\end{tabular}

Table 3. Hydrogen bonding parameters $\left(\AA{ }^{\circ}\right)$.

\begin{tabular}{lllll}
\hline $\mathrm{D}-\mathrm{H} \cdots \mathrm{A}$ & $\mathrm{D}-\mathrm{H}$ & $\mathrm{H} \cdots \mathrm{A}$ & $\mathrm{D} \cdots \mathrm{A}$ & $\mathrm{D}-\mathrm{H} \cdots \mathrm{A}$ \\
\hline $\mathrm{O} 1-\mathrm{H} 1 \mathrm{~A} \cdots \mathrm{O} 6$ & $0.83(2)$ & $1.82(2)$ & $2.650(2)$ & $177(3)$ \\
$\mathrm{O} 1-\mathrm{H} 1 \mathrm{~B} \cdots \mathrm{O} 3$ & $0.84(3)$ & $1.93(3)$ & $2.739(2)$ & $161(3)$ \\
O4-H4 $\cdots$ O $^{\mathrm{i}}$ & $0.820(3)$ & $1.720(3)$ & $2.527(2)$ & 168.8 \\
O8-H8A $\cdots$ O3 & $0.83(2)$ & $1.96(2)$ & $2.769(2)$ & $165(3)$ \\
O8-H8B $\cdots$ O7 & $0.85(3)$ & $1.87(2)$ & $2.699(2)$ & $165(4)$ \\
\hline Symmetry codes & i & $1-x, 2-y, 2-z$ & &
\end{tabular}

gles are listed in Table 2. The structure comprises a $\left[\mathrm{Co}\left(\mathrm{O}_{2} \mathrm{C}\left(\mathrm{CF}_{2}\right)_{8} \mathrm{CO}_{2} \mathrm{H}\right)(\text { phen })_{2}\left(\mathrm{H}_{2} \mathrm{O}\right)\right]^{2+}$ complex dication, a perfluorosebacate dianion and a water molecule. Within the complex cation, the cobalt(III) ion is six coordinate being bound to four nitrogen atoms [N1, N2, N3 and N4] of the chelating bidentate phenanthroline ligands, one oxygen atom of a unidentate perfluorosebacate ligand, $\left[\mathrm{O}_{2} \mathrm{C}\left(\mathrm{CF}_{2}\right)_{8} \mathrm{CO}_{2} \mathrm{H}\right]^{-}$, $[\mathrm{Co} 1-\mathrm{O} 2=2.1394(12) \AA]$ and one oxygen atom of a water molecule $[\mathrm{Co} 1-\mathrm{O} 1=2.0649(13) \AA]$ which is in a cisoid position with respect to the coordinated carboxylate ligand. The pendant carboxylate oxygen atoms of the perfluorosebacate [O4 and O5] are uncoordinated. There are one lattice water and one dianionic carboxylate ligand which are involved in hydrogen bonding (Fig. 1, Table 3).

The sixfold coordination around the cobalt atom differs from a regular octahedral geometry due to the small bite angles of the phenanthroline ligands [N1Co1-N2 $\left.=78.65(6)^{\circ}, \mathrm{N} 3-\mathrm{Co} 1-\mathrm{N} 4=78.36(6)^{\circ}\right]$. The three diagonal angles of the Co polyhedron are O1Co1-N3 $=170.22(6)^{\circ}, \mathrm{N} 1-\mathrm{Co} 1-\mathrm{N} 4=174.55(6)^{\circ}$ and $\mathrm{N} 2-\mathrm{Co} 1-\mathrm{O} 2=170.93(5)^{\circ}$. All Co-N bonds are slightly larger as compared to those in similar $\mathrm{Co}(\mathrm{III})$ compounds with an average of $2.1244 \AA$ [17]. The Co-N 


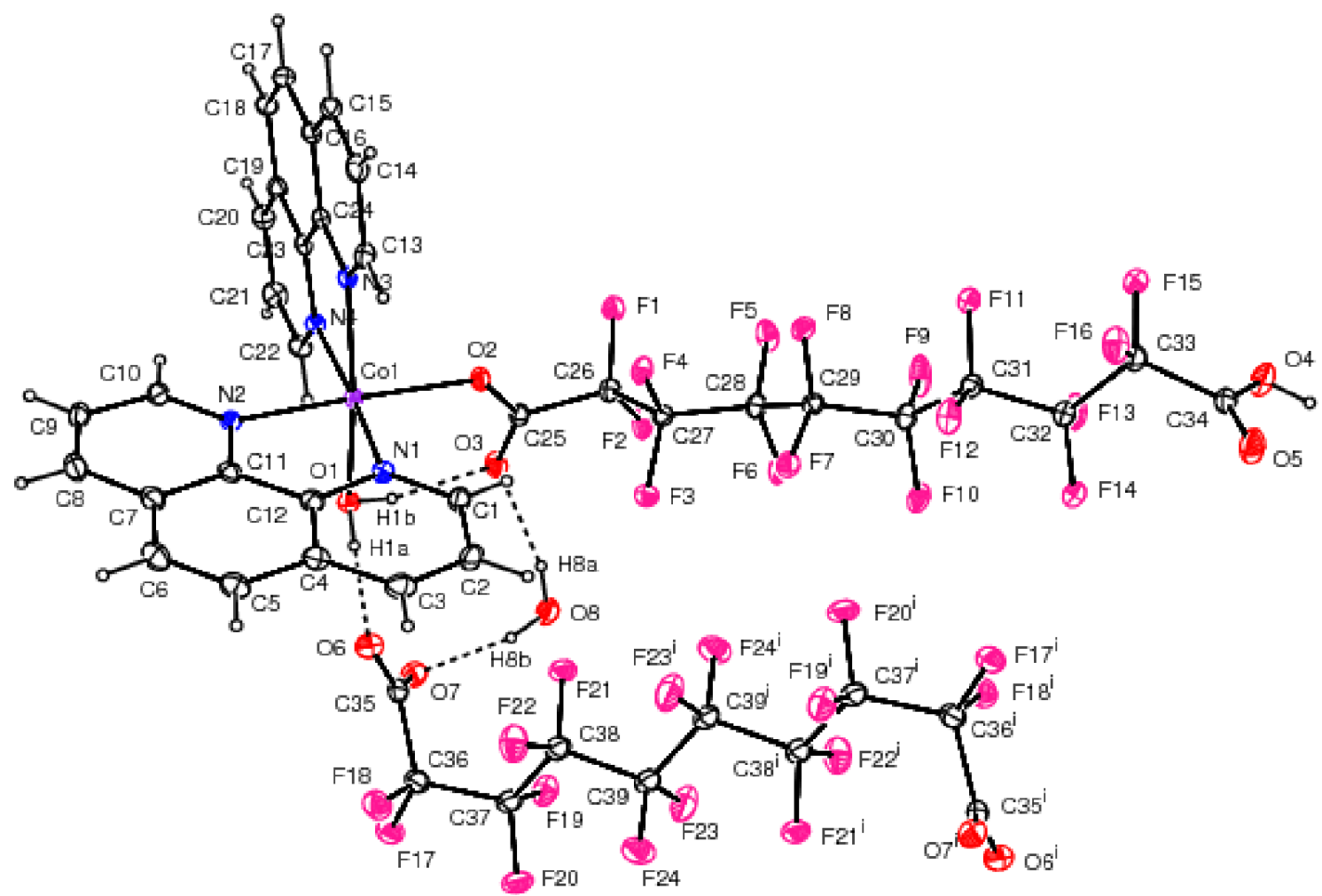

Fig. 1. View of complex 1 with displacement elipsoids (50\% probability) and atom labeling.

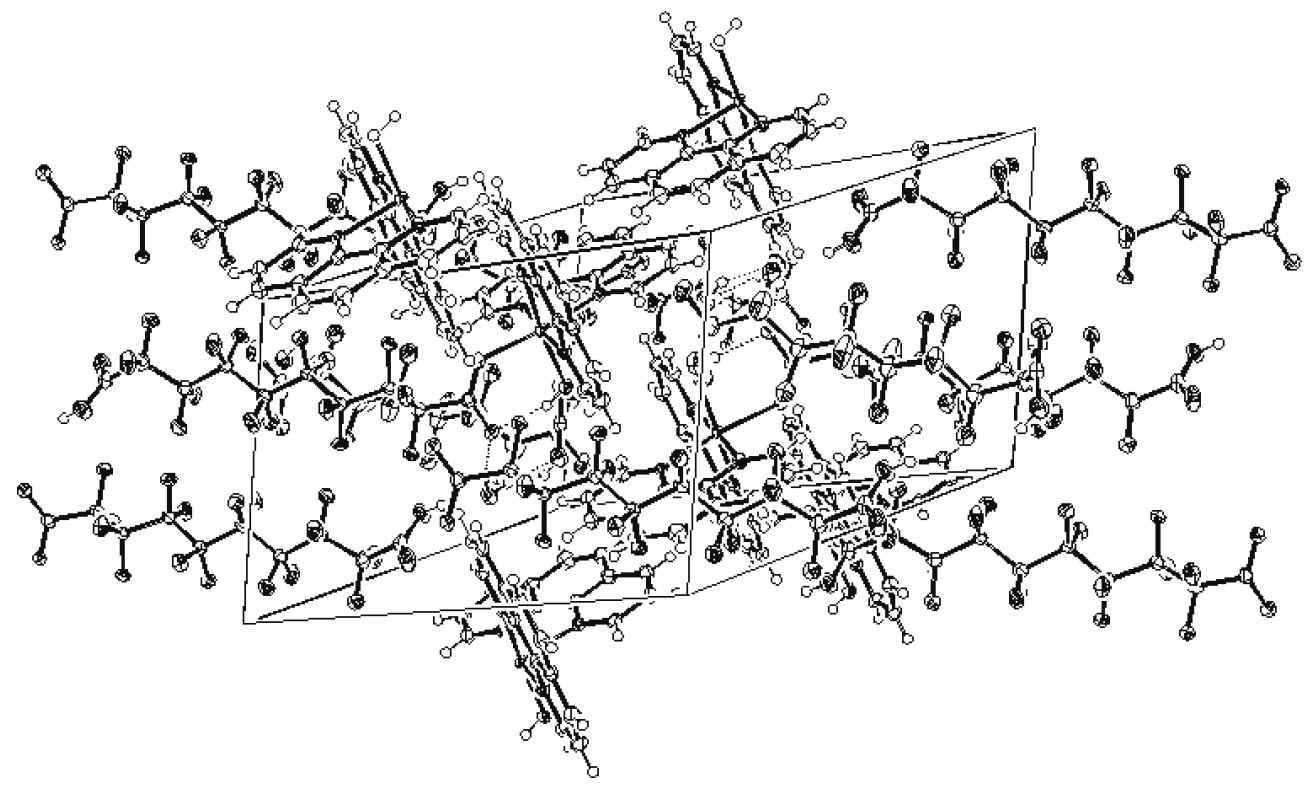

Fig. 2. The packing diagram of complex $\mathbf{1}$.

bond lengths of the apical positions are slightly shorter, $\quad \mathrm{Co}-\mathrm{N}$ bond lengths in the equatorial plane, $\mathrm{Co} 1-\mathrm{O} 2=$ Co1-N3 = 2.124(2) $\AA$, Co1-O1 = 2.064(2) $\AA$, than the $2.139(1) \AA$, Co1-N2 = 2.135(2) $\AA$. Around the central 


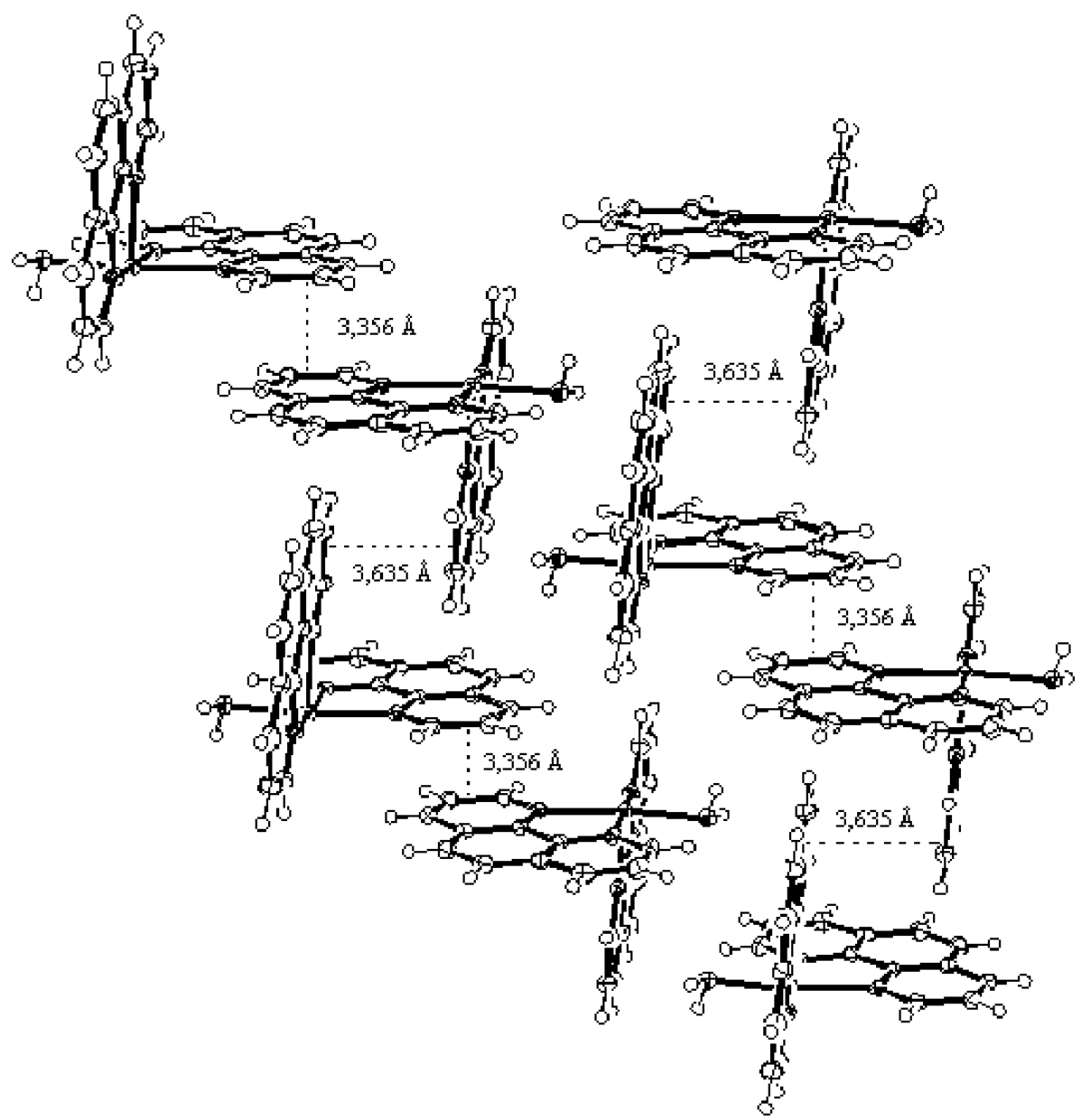

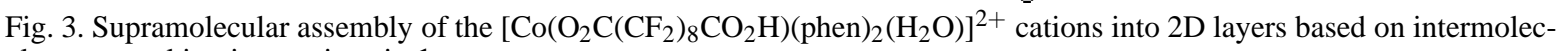
ular $\pi-\pi$ stacking interactions in $\mathbf{1}$.

Co atom, both chelating phen planes are nearly perpendicular to each other.

The uncoordinated linear perfluorosebacate dianion is crystallographically centrosymmetric. Its aliphatic chain has a planar, extended all anti geometry and its carboxyl oxygen atoms form pairs of strong hydrogen bonds $[\mathrm{O} 3 \cdots \mathrm{H} 1 \mathrm{~B}=1.93(3) \AA, 03 \cdots \mathrm{H} 8 \mathrm{~A}=1.96(2) \AA]$. The O ${ }^{\cdots} \mathrm{H} 1 \mathrm{~B}$ interaction is the only intramolecular hydrogen bonding between the uncoordinated carboxylate oxygen atom and the coordinated water molecule. In addition, there is extensive hydrogen bonding in the crystal, involving both coordinated and uncoordinated water molecules as well as the coordinated anionic ligand and the free dianion $\left[\mathrm{O} 7^{\cdots} \mathrm{H} 8 \mathrm{~B}=1.87(3) \AA\right.$, O6 $\left.{ }^{\cdots} \mathrm{H} 1 \mathrm{~A}=1.82(2) \AA\right]$. The analogous mononuclear complex $\left[\mathrm{Mn}\left(\mathrm{O}_{2} \mathrm{C}\left(\mathrm{CH}_{2}\right)_{5} \mathrm{CO}_{2}\right)(\text { phen })_{2}\left(\mathrm{H}_{2} \mathrm{O}\right)\right]$ has a similar coordination behavior [10]. The strongest in- termolecular hydrogen bonding interaction has been observed between the hydrogen atom of the coordinated carboxylate ligand and the oxygen atom of the solvated water molecule $\left[\mathrm{O}^{\mathrm{i}} \ldots \mathrm{H} 4=1.72 \AA\right]$. The packing diagram shows clearly $\pi-\pi$ stacking interactions (Fig. 3) between pairs of phen with characteristics interplanar distances between the rings of 3.356 and $3.635 \AA$, similar to known analogous $\mathrm{Mn}, \mathrm{Cu}, \mathrm{Zn}$ and Co complexes [18-19]. Obviously, both $\pi-\pi$ stacking and hydrogen bonding interactions are responsible for the supramolecular network assembly of complex $\mathbf{1}$.

\section{Electronic and IR spectra}

In the UV region, the intense multiple absorption bands (207, 226, $269 \mathrm{~nm})$ observed for complex 1 are presumably due to intraligand $\pi \rightarrow \pi^{*}$ and/or $n \rightarrow \pi^{*}$ transitions of the coordinated groups [20]. The free lig- 
ands also exhibit transitions (phen: 229 and 263; perfluorosebacic acid: $210 \mathrm{~nm}$ ). For the low spin $t_{2 g}{ }^{6}$ configuration of $\mathrm{Co}$ (III) complexes two spin allowed transitions, ${ }^{1} A_{1 g} \rightarrow{ }^{1} T_{1 g},{ }^{1} A_{1 g} \rightarrow{ }^{1} T_{2 g}$ are expected usually around $500 \mathrm{~nm}$ and two spin-forbidden transitions, ${ }^{1} A_{1 g} \rightarrow{ }^{3} T_{1 g},{ }^{1} A_{1 g} \rightarrow{ }^{3} T_{2 g}$, at higher energies which are usually difficult to assign owing to overlap of interligand and charge transfer transitions [21,22]. The expected weak $d$ - $d$ transitions in the visible region for complex 1 have not been detected even for concentrated solutions. It may be lost in the low-energy tail of the intense charge-transfer transitions. The band at $263 \mathrm{~nm}$ is red shifted by about $\sim 9 \mathrm{~nm}$ from the corresponding absorption of the free ligand.

In the IR spectrum of complex $\mathbf{1}$, the strong broad peak centered at $3422 \mathrm{~cm}^{-1}$ includes the $v_{\mathrm{OH}}, v_{\mathrm{N}-\mathrm{H}}$, and $v_{\mathrm{Ar}-\mathrm{H}}$ vibrations of the ligands. The peaks around at $3400 \mathrm{~cm}^{-1}\left(v_{\mathrm{O}-\mathrm{H}}\right)$ and $1426\left(v_{\text {bending }}\right) \mathrm{cm}^{-1}$ are the characteristics of lattice water molecules. The characteristic bands of the C-F stretching appear in the 1228 $1143 \mathrm{~cm}^{-1}$ region. The bands at 848 and $727 \mathrm{~cm}^{-1}$ are assigned to the $\mathrm{C}-\mathrm{H}$ out of plane bending of the phen ligands. Bands due to vibrations of the carboxylate ligand are broad strong peaks at $1668 \mathrm{~cm}^{-1}$ for antisymmetric and at $1393 \mathrm{~cm}^{-1}$ for symmetry stretching. The separation $(\Delta)$ between $v_{\mathrm{as}}\left(\mathrm{COO}^{-}\right)$and $v_{\mathrm{s}}\left(\mathrm{COO}^{-}\right)$ is $270 \mathrm{~cm}^{-1}$, indicating a mono-dentate coordination mode for the coordinated carboxylate group [23, 24]. The absorption at $1760 \mathrm{~cm}^{-1}$ assigned to asymmetrical stretching of free carboxyl groups is showing a shift towards low frequency when compared to $v_{\text {as }}\left(\mathrm{COO}^{-}\right)$ $\left(1668 \mathrm{~cm}^{-1}\right)$ of carboxylic acid in which intra- and intermolecular hydrogen-bonding weakens the $\mathrm{C}=\mathrm{O}$ bond in the carboxyl group. These IR results agree with the result of the X-ray diffraction analysis.

\section{Thermal analysis}

The thermal decomposition of the complex was studied by thermogravimetry (TG) under argon atmosphere from 50 to $980{ }^{\circ} \mathrm{C}$ (Fig. 4). Complex 1 decomposes via endothermic solid state reactions. The TG data show that decomposition occurs in several steps. Loss of water between 121 and $138{ }^{\circ} \mathrm{C}$ corresponds to weight loss of $2.4 \%$ (calcd. $2.5 \%$ ). The release of lattice water molecule at such a high temperature is probably due to strong coordinative and hydrogen bonds. Phenanthroline ligands and uncoordinated perfluorosebacate units are lost between 200 and $326{ }^{\circ} \mathrm{C}$ (weight loss $59.2 \%$, calcd. 58.6\%). The final decomposition

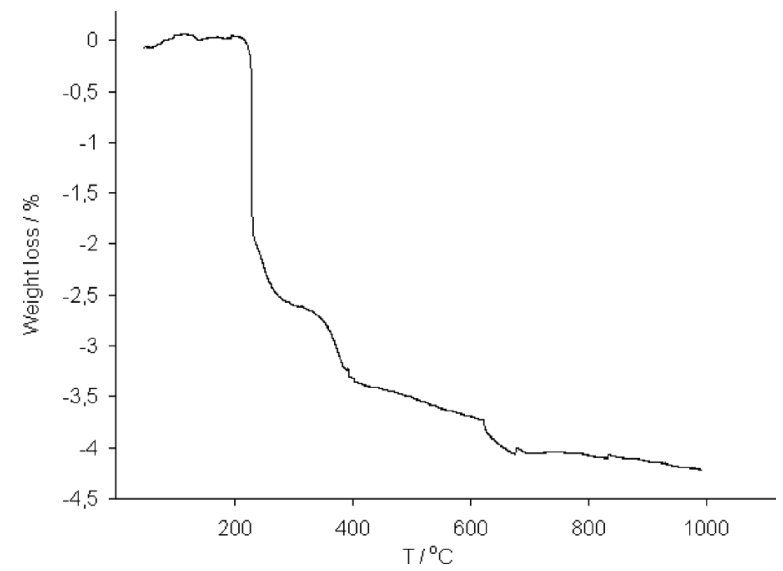

Fig. 4. The TG curve for complex 1 in the range of $50-$ $980{ }^{\circ} \mathrm{C}$ (weight taken $=4.607 \mathrm{mg}$ ).

corresponds to the release of the coordinated perfluorosebacate ligand (weight loss $33.9 \%$, calcd. $34.1 \%$ ).

In conclusion, a mixed-ligand $\mathrm{Co}(\mathrm{III})$ complex has been synthesized and its composition and crystal structure have been determined as $\left[\mathrm{Co}(\mathrm{HL})(\right.$ phen $\left.)\left(\mathrm{H}_{2} \mathrm{O}\right)\right]-$ (L) $\mathrm{H}_{2} \mathrm{O}$ by $\mathrm{X}$-ray diffraction, elemental and thermal analysis. It features a supramolecular network via hydrogen bonding and $\pi$ - $\pi$ stacking interactions.

\section{Experimental Section}

Materials and instrumentation

All chemicals were commercially available in $p$. $a$. grade and used without further purification. Elemental analysis was performed on a VARIO ELIII CHNOS Elemental Analyzer. FT-IR spectra were recorded on a JASSCO FT/IR-300E spectrophotometer using $\mathrm{KBr}$ pellet technique in the range of $4000-400 \mathrm{~cm}^{-1}$. The electronic spectra were carried out on a SHIMADZU UV-2450 spectrophotometer. Thermogravimetric analyses were carried out with a SETERAM LabsysDTA 1600:amb $1.600{ }^{\circ} \mathrm{C}$ unit at a heating rate of $5^{\circ} \mathrm{C} / \mathrm{min}$ under argon atmosphere. Magnetic susceptibility measurement at r.t. was performed using a Sherwood Scientific MXI model Gouy magnetic balance.

\section{Preparation of $\left[\mathrm{Co}(\mathrm{HL})(\text { phen })_{2}\left(\mathrm{H}_{2} \mathrm{O}\right)\right](\mathrm{L}) \cdot \mathrm{H}_{2} \mathrm{O}(\mathbf{1})$}

Addition of $0.5 \mathrm{ml}(1 \mathrm{M}) \mathrm{Na}_{2} \mathrm{CO}_{3}$ to a stirred solution of $\mathrm{Co}\left(\mathrm{NO}_{3}\right)_{2} \cdot 6 \mathrm{H}_{2} \mathrm{O}(118.7 \mathrm{mg}, 0.408 \mathrm{mmol})$ in $10 \mathrm{ml}$ of $\mathrm{H}_{2} \mathrm{O}$ yielded a precipitate, which was separated by filtration, washed with distilled water several times and finally added to a stirred solution of phenanthroline monohydrate (80.78 $\mathrm{mg}, 0.408 \mathrm{mmol})$ and perfluorosebacic acid $(200 \mathrm{mg}$, $0.408 \mathrm{mmol})$ dissolved in $20 \mathrm{ml}$ of $\mathrm{EtOH} / \mathrm{H}_{2} \mathrm{O}(1: 1 \mathrm{v} / \mathrm{v})$. The mixture was stirred for $c a .2 \mathrm{~h}$. The orange solution 
was allowed to stand at r.t. Slow evaporation for 2 weeks afforded orange crystals. M. p. $143{ }^{\circ} \mathrm{C}$, yield $310 \mathrm{mg}(64 \%)$. Analysis for $\mathrm{C}_{44} \mathrm{H}_{21} \mathrm{~N}_{4} \mathrm{O}_{10} \mathrm{~F}_{32} \mathrm{Co}$ (1432.5): calcd. C 36.89, H 1.48, N 3.91; found C 38.61, H 1.76, N 4.81. - FT-IR $(\mathrm{KBr}): v=3422,1938,1761,1668,1581,1518,1426,1440$, $1393,1355,1274,121,1147,1070,968,868,848,757,727$, $644,556,524 \mathrm{~cm}^{-1}$.

\section{$X$-ray data collection and structure determination [25]}

A suitable single crystal was mounted on a glass fiber and data collection was performed on a STOE IPDS II image plate detector using $\mathrm{MoK}_{\alpha}$ radiation $(\lambda=0.71019 \AA)$. Intensity data were collected in the $\theta$ range $1.88-26.00^{\circ}$ at $100(2) \mathrm{K}$. The crystallographic data along with some details of data collection and structure refinement are given in Table 1. Data collection: Stoe X-AREA [26]. Cell refinement: Stoe X-AREA. Data reduction: Stoe X-RED. The struc- ture was solved by Direct Methods using SHELXS-97 [27]. Anisotropic displacement parameters were applied to nonhydrogen atoms in a full-matrix least-squares refinement based on $F^{2}$ using SHELXL-97. All hydrogen atoms except the ones refined freely and bonded to water oxygen atoms were positioned geometrically and refined by a riding model with $U_{\text {iso }} 1.2$ times (for carbon) and 1.5 times (for oxygen) that of attached atoms. Molecular drawings were obtained using ORTEP-III [28].

\section{Acknowledgements}

The authors wish to acknowledge Anadolu University, Commission of Scientific Research Projects for financial support (Project No: 031036) and the Faculty of Arts and Sciences, Ondokuz Mayis University, Turkey, for the use of the STOE IPDS II diffractometer (purchased under grant F.279 of the University Research Fund).
[1] M. Petric, F. Pohleven, I. Turel, P. Segedin, A. White, D. Williams, Polyhedron 17, 255 (1998).

[2] M. Devereux, M. McCann, V. Leon, M. Geraghty, V. McKee, J. Wikaria, Polyhedron 19, 1205 (2000); M. Devereux, M. McCann, V. Leon, R. Kelly, D. O'Shea, V. McKee, Polyhedron 22, 3187 (2003).

[3] K. E. Erkkila, D. T. Odom, J. Barton, Chem. Rev. 99, 2777 (1999); L.-N. Ji, X.-H. Zou, J.-G. Liu, Coord. Chem. Rev. 216, 513 (2001); W.-L. Wang, H. Chao, H. Li, X.-L. Hong, Y.-J. Liu, L.-F. Tan, L.-N. Ji, J. Inorg. Biochem. 98, 1143 (2004); J. Zheng, Z. Li, A. Wu, H. Zhou, H. Bai, Y. Song, Biochem. and Biophys. Commun. 299, 910 (2002); Q.-L. Zhang, J.-H. Kiu, X.-Z. Ren, H. Xu, Y. Huang, J.-Z. Liu, L.-N. Ji, J. Inorg. Biochem. 95, 194 (2003); S. Srinivasab, J. Annaraj, P. R. Athappan, J. Inorg. Biochem. 99, 876 (2005); X.-F. He, L. Wang, H. Chen, L. Xu, L.-N Ji, Polyhedron 17, 3161 (1998).

[4] C. M. R. Juan, B. Lee, Coord. Chem. Rev. 183, 43 (1999); S. McCann, M. McCann, M. T. Casey, M. Devereux, V. McKee, P. McMichael, J. G. McCrea, Polyhedron 16, 4247 (1997).

[5] T. N. Guru Row, Coord. Chem. Rev. 183, 81 (1999); S. S. Kuduva, D. C. Craig, A. Nangia, G. R. Desiraju, J. Am. Chem. Soc. 121, 1936 (1999); O. Felix, M. W. Hosseini, A. deCian, J. Fischer, Angew Chem., Int. Ed. Engl. 36, 102 (1997); P. Brunet, M. Smard, J. D. Wuest, J. Am. Chem. Soc. 119, 2737 (1997).

[6] M. Munakata, L.P. Wu, M. Yamamoto, T. KurodaSowa, M. Maekawa, J. Am. Chem. Soc. 118, 3117 (1996); P. J. Hargman, D. Hargman, J. Zupieta, Angew. Chem. Int. Ed. 38, 2638 (1999).

[7] B. Moulton, M. J. Zaworotko, Chem. Rev. 101, 1629 (2001); Y. Q. Zheng, J.L. Lin, B. Y. Chen, J. Mol. Struc. 646, 151 (2003).
[8] J. Tercero, C. Diaz, M. E. Fallah, J. Ribas, X. Solans, M. A. Maestro, J. Mahia, Inorg. Chem. 10, 3007 (2001).

[9] Y. S. Xie, H. Jiang, M. G. Yu, C. X. Du, Q. L. Liu, X. L. Xu, Y. Zhu, J. Mol. Struct. 608, 169 (2002).

[10] M. McCann, M. T. Casey, M. Devereux, M. Curan, G. Ferguson, Polyhedron 16, 2547 (1997).

[11] M. Devereux, M. McCann, J. F. Cronin, V. Ferguson, V. McKee, Polyhedron 18, 214 (1999).

[12] M. McCaan, M. T. Casey, M. Devereux, M. Curran, V. McKee, Polyhedron 16, 2741 (1997); D. Y. Wei, Z. P. Kong, Y. Q. Zheng, Polyhedron 21, 1621 (2002).

[13] M. Devereux, M. McCann, J. F. Cronin, V. Ferguson, V. McKee, Polyhedron 18, 2141 (1999).

[14] Y. Q. Zheng, Z. P. Kong, J. Solid Stat. Chem. 166, 279 (2002).

[15] D. Maiti, H. Paul, N. Chanda, S. Chakraborty, B. Mondal, V. G. Puranik, G. K. Lahiri, Polyhedron 23, 831 (2004).

[16] R. P. John, A. Sreekanth, R. Maliyeckal, P. Kurup, S. M. Mobin, Polyhedron 21, 2515 (2002).

[17] K. Larsson, L. Öhrström, Inorganica Chimica Acta 357, 657 (2004); J. Abdelhak, S. M. Cherni, T. Jouni, Analytical Sciences x65 (2004).

[18] Y. Q. Zheng, J. L. Lin, Z. P. Kong, Polyhedron 22, 2699 (2003); Y. Q. Zheng, Z. P. Kong, J. Solid Stat. Chem. 177, 1352 (2004); Y. Q. Zheng, E. B. Ying, Polyhedron 24, 397 (2005).

[19] M. Geragthy, M. McCann, M. Devereux, V. McKee, Inorg. Chim. Acta 293, 160 (1999).

[20] S. Chakraborty, M. G. Walawalkar, G. K. Lahiri, J. Chem. Soc. Dalton. Trans. 2875 (2000); D. Maiti, H. Paul, N. Chanda, S. Chakraborty, B. Mondal, V. G. Puranik, G. K. Lahiri, Polyhedron 23, 831 (2004). 
[21] M. B. Ferrari, G. G. Fawa, C. Pelizzi, P. Tarasconi, J. Chem. Soc., Dalton Trans. 2153 (1992).

[22] M. B. Ferrari, G. G. Fawa, C. Pelosi, M. C. RodriguezAgüelles, P. Tarasconi, J. Chem. Soc., Dalton Trans. 3035 (1995)

[23] G. B. Deacon, R. J. Phillips, Coord. Chem. Rev. 33, 227 (1980).

[24] K. Nakamoto, Infrared and Raman Spectra of Inorganic and Coordination Compounds, Wiley, New York (1986).

[25] Crystallographic data (excluding structure factors) for the structure reported in this paper have been deposited with the Cambridge Crystallographic Data Centre as the supplementary publication no. CCDC 271461. Copies of the data can be obtained free of charge from The Cambridge Crystallographic Data Center via www.ccdc.cam.ac.uk/data_request/cif.

[26] Stoe \& Cie X-AREA (Version 1.18) and X-RED32 (Version 1.04). Stoe \& Cie, Darmstadt, Germany (2002).

[27] G. M. Sheldrick, SHELXS97 and SHELXL-97, University of Göttingen, Germany (1997).

[28] M. N. Burnett, and C. K. Johnson, ORTEPIII. Report ORNL-6895. Oak Ridge National Laboratory, Tennessee, U.S.A. (1996). 